\title{
THE BIG CHILL \\ Italian Family Budgets after the Great Recession
}

\author{
Andrea Brandolini
}

In the first nine months of 2013, the real per capita disposable income of Italian households went down by 2.1 percent relative to one year earlier. This brought the overall fall since the corresponding period of 2007, prior to the outbreak of the global financial crisis, to almost 13 percent. This decline follows a prolonged stagnation that has caused household real incomes to fall back to the levels recorded in 1988 in per capita terms. People have cushioned the negative effects on their living standards by reducing savings and decreasing wealth holdings. Yet the proportion of individuals who regard their family economic resources as inadequate has increased from 39 percent in 1993 to 50 percent in 2013. The failure of Italian households to improve their finances for a quarter of a century is unprecedented in the country's post-war record (see fig. 1 for the period 1960-2013).

These trends are the consequence of the lasting and pronounced slowdown of the Italian economy. Their explanation calls for an understanding of the deep-rooted causes of Italy's "growth problem," an issue that is beyond the scope of this chapter. ${ }^{1}$ The focus here is on the distributive dimension of these trends. The questions addressed include whether aggregate income losses were generally shared by Italian households or whether they hit some households more than others, and if they were accompanied by a widening of the distribution and a deterioration of poverty indicators.

The chapter is organized as follows. The next section considers the evolution of household budgets in the aggregate, in the period marked 
FIGURE 1 Gross Domestic Product and Household Finances, 1960-2013 (at constant prices and per capita)

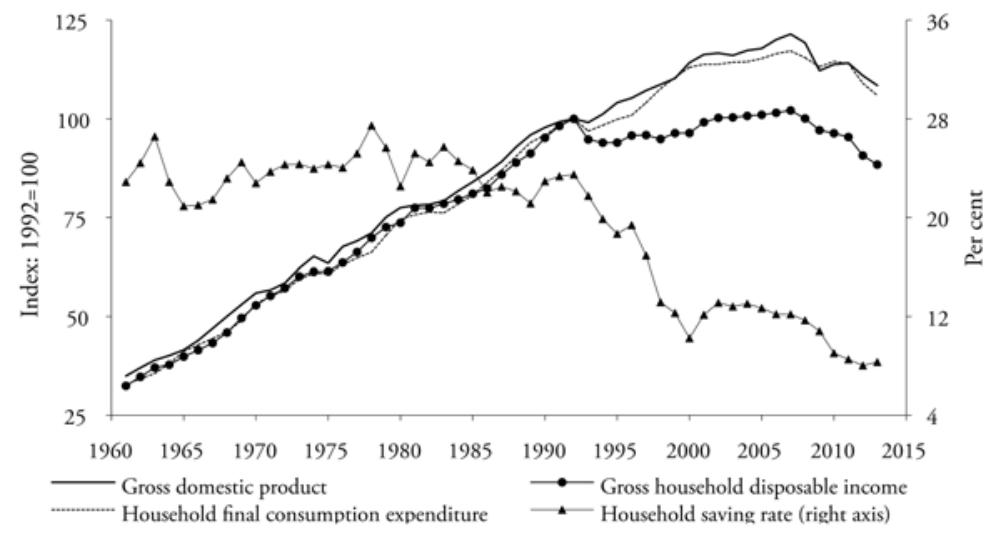

Source: Elaboration on data from ISTAT, Annuario di contabilità nazionale, vol. III edizione 1973, tomo I (Rome: ISTAT, 1973); ISTAT, Conti nazionali economici e finanziari dei settori istituzionali: Anni 1980-88 (Rome: ISTAT, 1991); ISTAT, Conti economici e finanziari dei Settori istituzionali, dischetto con le serie 19801996 (Rome: ISTAT, 1997); ISTAT, National Accounts, http://dati.istat.it/ (accessed on 28 January 2014); and P. Pagliano and N. Rossi, "The Italian Saving Rate: 1951 to 1990 Estimates," in Income and Saving in Italy: A Reconstruction, ed. G. Marotta, P. Pagliano, and N. Rossi (Rome: Bank of Italy, 1992).

by the Great Recession of 2008-2009 and the sovereign debt crisis of 2011-2013. The following sections investigate the distribution of consumption expenditure and poverty levels, the composition of the poor and material deprivation, developments in the labor market and the distribution of income among taxpayers, and the distributions of household income and wealth. The final section summarizes the main points and concludes by touching on a far more speculative question: will today's young generations be the first since World War II, and possibly since the country's unification in 1861, to fail to improve their economic condition over that of older generations?

\section{The Great Recession, the Sovereign Debt Crisis, and Household Finances}

In the last quarter of 2008, the crisis of global financial markets that had begun in 2007 turned into a dramatic collapse of world trade. For most 
advanced economies, it was the start of the worst downturn since World War II, later labeled "the Great Recession." In Italy, intense subcontracting relations and banks' tightening of lending conditions helped to propagate the rapid and sharp drop in foreign demand to the rest of the economy. ${ }^{2}$ By the second quarter of 2009, real gross domestic product (GDP) had declined by 7.2 percent relative to the peak reached in the first quarter of 2008, far more than in most other European countries. The downturn was largely caused by external factors, with the deterioration of business confidence and domestic financing conditions playing only a minor role. ${ }^{3}$ Alas, this pattern was not mirrored by stronger growth when world demand rebounded. In the second quarter of 2011, Italy's real GDP had gone up by only 2.9 percent with respect to the low point of the Great Recession. This was similar to the increase in the United Kingdom and more than in Spain, but it was less than in France and especially in Germany and Sweden. The harder blow of the Great Recession and the slower recovery afterward can be seen as further manifestations of the Italian economy's growth problem.

The sovereign debt crisis of 2011 plunged Italy back into recession. Through the third quarter of 2013, real GDP dropped further by 4.8 percent with respect to the second quarter of 2011. This second recession differs from the previous one in being driven mainly by internal factors. In comparing the actual macro-economic pattern in 20122013 with the counter-factual scenario corresponding to that forecast in the summer of 2011, Busetti and Cova estimate that the slowdown of the world economy accounts for less than a third of the loss in real GDP growth. ${ }^{4}$ Among internal factors, it is the impact of government intervention that is noticeably different, as the stimulus to economic activity in the first recession was replaced by a fiscal consolidation in the second recession. Almost half of the estimated worsening in the dynamics of real household consumption (more than eight percentage points over the two years) is attributable to the austerity packages adopted since $2011 .^{5}$

This change in the orientation of fiscal policy is an important factor behind the different dynamics of the gross household disposable income (GHDI) as compared to those of GDP (fig. 2). Although real GHDI fell throughout the period 2009-2013, it declined less intensely than real GDP during the Great Recession, when the government recorded a primary deficit (-0.8 percent of GDP in 2009). ${ }^{6}$ The opposite has happened in the current recession, characterized by a total primary surplus of almost 5 percent of GDP over two years, 2012 to 2013.

Jenkins et al. stress the crucial role that the public budget played in cushioning the impact of the Great Recession on household finances 
FIGURE 2 Change in Gross Domestic Product and Household Finances, 2004-2013 (cumulated figures, percentage points for the household saving rate, \% otherwise)

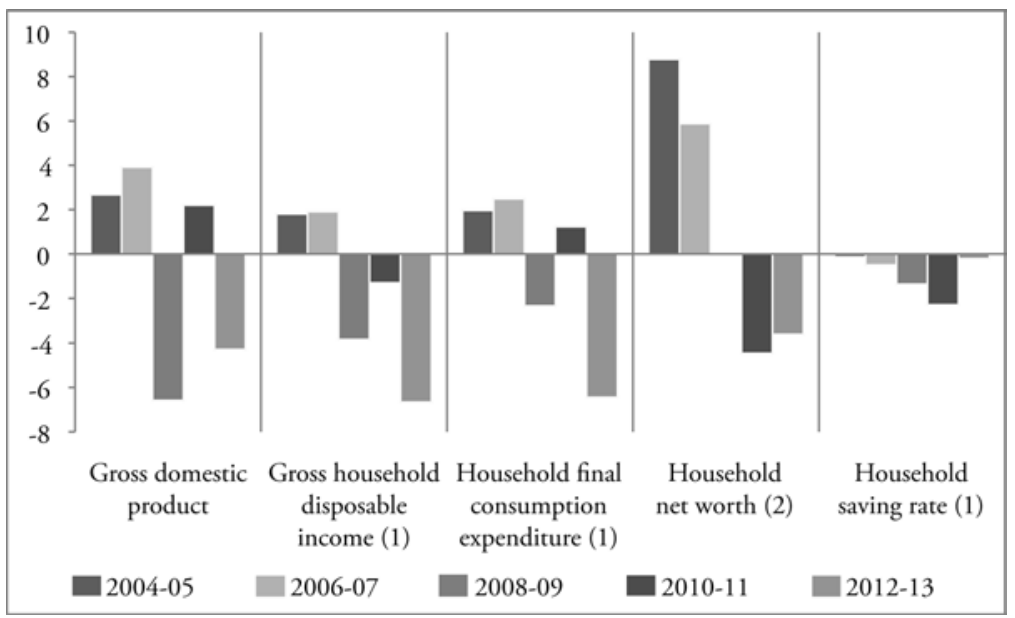

Notes: (1) Includes consumer households and non-profit institutions serving households; (2) includes consumer households and sole proprietorships with five employees or less; average of end-of-year value for current year and corresponding value for preceding year; change for 2012-2013 refers to 2012 only. Source: Elaboration on data from ISTAT, National Accounts; A. Alivernini and D. Caprara, "Household Wealth in Italy: 2012," Supplement to the Statistical Bulletin, Monetary and Financial Indicator No. 65, Bank of Italy, Rome, 2013.

in the OECD countries. Comparing changes in real GHDI and real GDP between 2007 and 2009 in 18 OECD countries, they observe: "[T]he most striking feature is the prevalent pattern of increases in GHDI despite the almost universal falls in output." They subsequently conclude that "the protection of household incomes against the collapse of economic activity during the Great Recession was largely provided by the government." 7 The contrast is conspicuous between Sweden and Finland, on one side, and Italy, on the other: in the face of real GDP losses similar in size, real household incomes rose by $4-5$ percent in the two Nordic countries but fell by 4 percent in Italy. The different extent to which taxes and social contributions declined and social benefits increased accounts for a large part of the discrepancy. In Italy, both a less-developed social safety net and a more restrained government counter-cyclical response, due to the already precarious situation of public finances, led to lower public support to family budgets. 
Nevertheless, even in Italy, net government transfers were crucial to prevent a larger fall in household incomes. In figure 3, changes in GHDI are broken down into the contributions of four main components: compensation of employees, income from self-employment, property income and other private transfers, and social benefits net of taxes and social contributions. Variables are defined in the note to the figure. For each sub-period, the bars for the four components add up to the bar for GHDI shown in the far-right panel. During the Great Recession (2008-2009) and the next two years (2010-2011), all revenues from labor or property dropped. Only the net balance between benefits received and taxes paid provided a positive contribution, although to a lesser extent in the second sub-period. This support vanished in 2012, and most likely again in 2013, as the fiscal packages adopted in 2011 came into effect.

FIGURE 3 Contributions to Changes in Gross Household Disposable Income (percentage points)

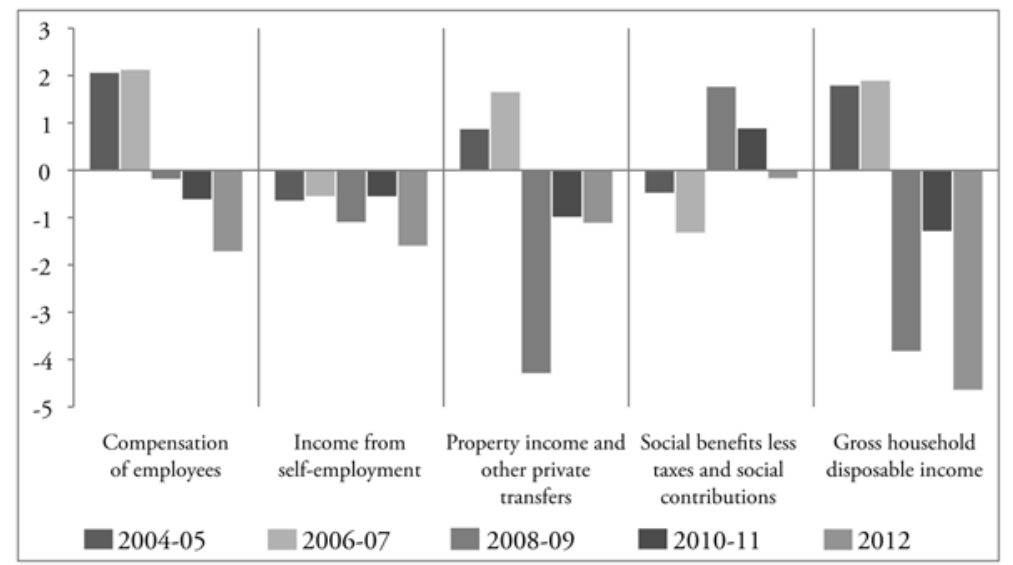

Note: Households include consumer households and non-profit institutions serving households. Compensation of employees: wages and salaries before taxation and social contributions; income from self-employment: mixed income transferred from sole proprietors to their households; property income and other private transfers: imputed income from rent for owner-occupiers, received dividends and other distributed income of corporations, interest from bank accounts, government bonds and private securities, rents, and other current private transfers, all net of the amounts paid; social benefits net of taxes and social contributions: all public transfers other than those in kind less current taxes on income and wealth and social insurance contributions paid by employers and employees.

Source: Elaboration on data from ISTAT, National Accounts. 
Figure 3 also shows that plummeting interest, dividends, and other distributed profits substantially contributed to reduce GHDI. Without their fall, household disposable income would have remained virtually stable in 2008-2009 and 2010-2011. This is not the only channel through which the housing and financial markets affect household finances, however. Changes in asset values may cause capital gains or losses that are not included in disposable income by definition, but may nonetheless influence household consumption behavior. ${ }^{8}$ The Italian housing market has not experienced the bust that occurred in other countries such as Ireland, the Netherlands, Spain, and the United Kingdom. ${ }^{9}$ The number of transactions decreased sharply, by approximately one-half in the last five years, but housing prices remained close to the high levels of 2008 until the end of 2011, after which they dropped by around 9 percent. Conversely, share prices plummeted during the Great Recession and again during the sovereign debt crisis. At the end of 2012, the Total Return Index for the Italian stock exchange estimated by Morgan Stanley Capital International, which is an equity price index embodying full reinvestment of dividends, had fallen to exactly half the peak reached in May 2007. The overall fall was still equal to just 42 percent at the end of 2013. These price variations produced considerable capital losses. In the five years 2008-2012, they totaled one year of GHDI, two-thirds of which incurred on real assets and the remaining third on financial assets. ${ }^{10}$ These are sizable numbers that could account for a reduction in annual consumption by as much as half a percentage point. ${ }^{11}$ During that period, household net wealth fell by about 8 percent in real terms (fig. 2).

Since the recession of the early 1990s, capital gains and a considerable reduction in the propensity to save have been important to sustain consumption in a period of subdued growth of real household income. Indeed, household expenditure tracked GDP more than GHDI until the sovereign debt crisis, as shown in figure 1. This has, however, changed in the last couple of years as capital losses have become substantial. On a per capita basis, real consumption in 2013 is expected to decrease by more than 9 percent with respect to 2007 , against a 13 percent fall in real GHDI.

\section{The Distribution of Household Consumption and the Poverty Levels}

By its sheer size, the deterioration of household finances raises understandable concerns over the living standards of Italian households. From this perspective, the analysis needs to move beyond the mean values 
of income and expenditure and consider how they are spread across the population. Household-level information on expenditure is available from ISTAT's Household Budget Survey (HBS), a long-established annual survey, the main purpose of which is to collect the detailed expenditure data used in the estimation of cost-of-living indices and national accounts. The HBS is also a primary source for the calculation of poverty statistics. In this section, the HBS data from the public-use data files are utilized to study the overall distribution of expenditure.

Consistently with the definition used for poverty estimates, monthly expenditure is computed as the sum of all expenses for consumption goods and services plus the imputed rent of owner-occupied dwellings. Extraordinary spending for dwelling maintenance, mortgage payments, and premiums paid for life insurances and annuities are excluded on the grounds that they are forms of capital accumulation. ${ }^{12}$ As households differ in size and composition, the same nominal level of household expenditure (or income, for that matter) may correspond to different standards of living. Cohabitation generates significant economies of scale in consumption, since, for instance, heating expenses rise less than proportionately to the number of household members. By applying the equivalence scale used in official statistics, expenditure levels are made comparable, in welfare terms, across households of different size, taking a two-member household as the reference. ${ }^{13}$ Equalized expenditure is then attributed to all household members in order to consider the distribution among persons rather than households. This avoids giving the same weight to a single person and to a large household in the measurement of social welfare. For time comparisons, real figures are obtained by dividing current price values by the national accounts deflator of household final consumption.

From 2008 to 2012, real equalized household expenditure fell on average by 10.4 percent, after increasing by 4.2 percent in the preceding five years. ${ }^{14}$ Figure 4 compares these mean changes with those at different points of the expenditure distribution, namely, at the nine deciles D1-D9. ${ }^{15}$ All in all, the increase in the period 2003-2007 was fairly uniform across the distribution. The subsequent fall was shared by all deciles, but was smaller in the middle and far larger at both the bottom and the top: the fall roughly doubles from 6.6 percent at D6 to 14.4 percent at $\mathrm{D} 1$, on the one side, and 12.4 percent at $\mathrm{D} 9$, on the other. The approximate symmetry of these variations explains why the Gini coefficient, a summary measure of inequality ranging from 0 to 1 , remained virtually constant at 31 percent (table 1 ).

The worsening at the bottom of the expenditure distribution is reflected in the rise of poverty ratios. Following ISTAT, ${ }^{16}$ several indicators are plotted in figure 5 for the years 1998-2012 (see also table 1). 


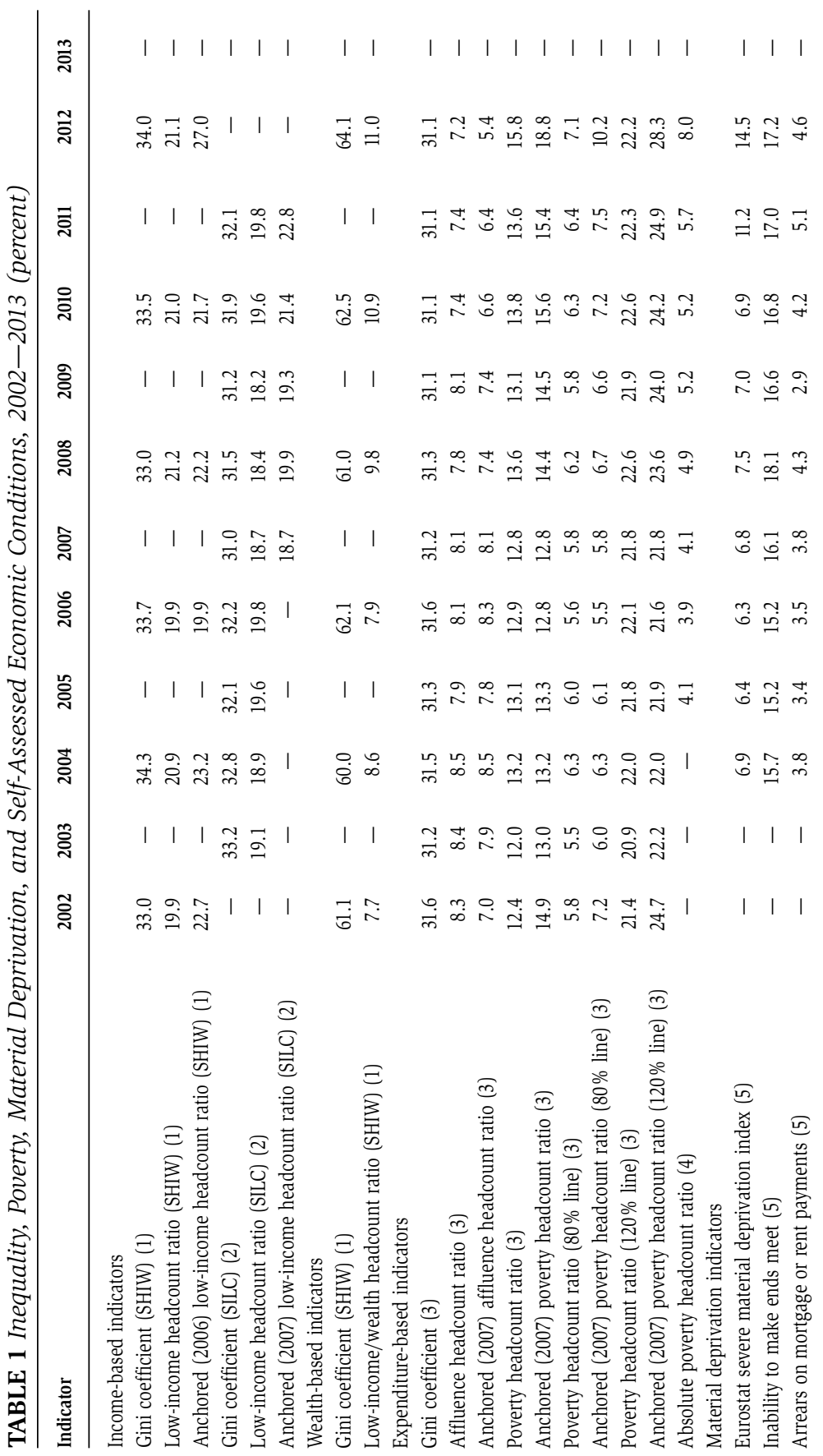




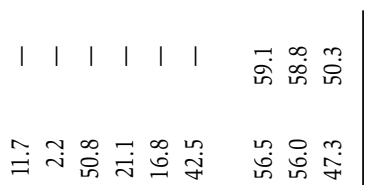

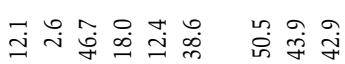

恣

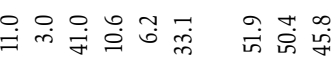

목

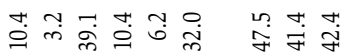

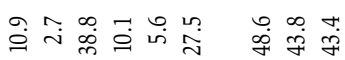

恣

它

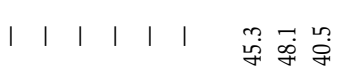

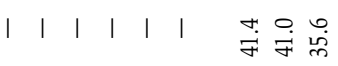

近包 $\pi$

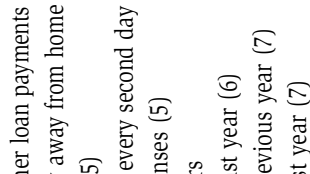

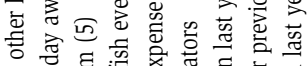

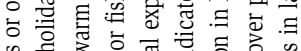

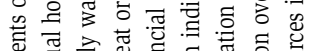

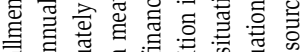

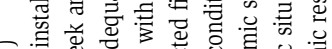

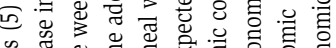

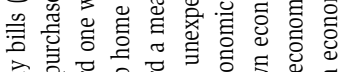

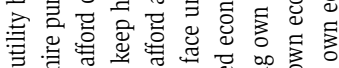
ธี

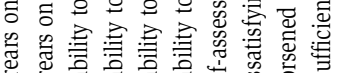

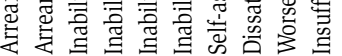

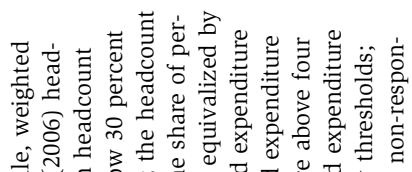

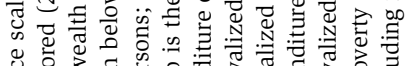

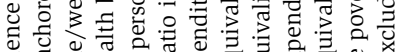

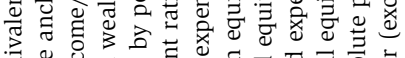

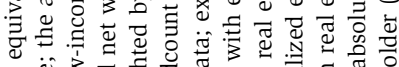

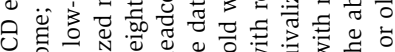

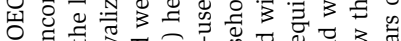

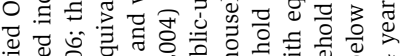

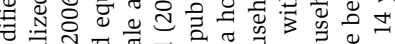

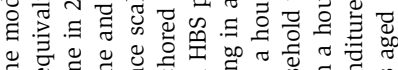

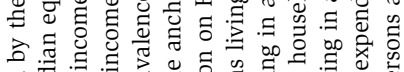

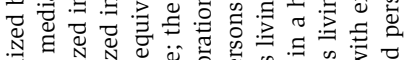

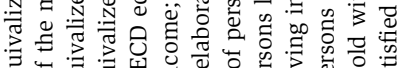

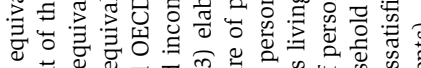

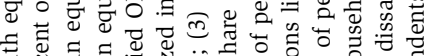

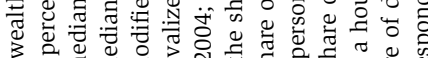

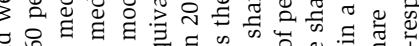

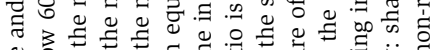

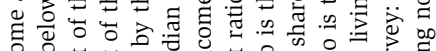

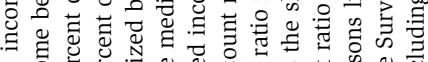

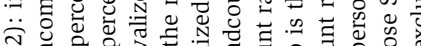

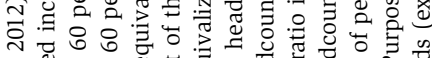

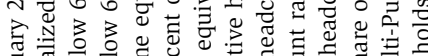

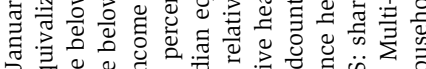

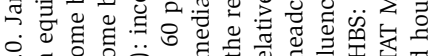
厾.

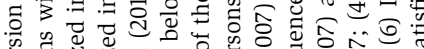

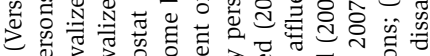

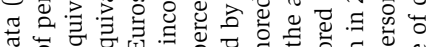

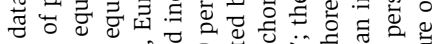

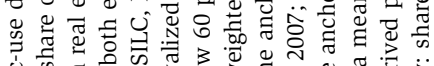

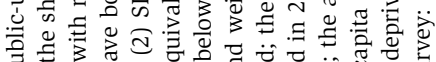

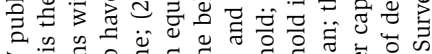

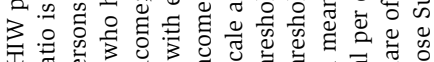

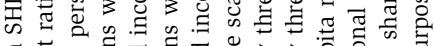

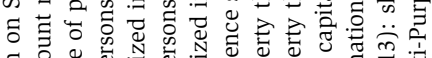

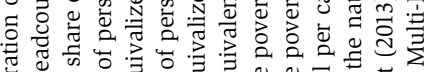

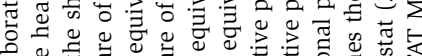
等

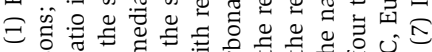
论

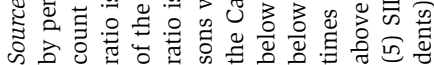


FIGURE 4 Changes in Household Equivalized Consumption Expenditure, by Decile (percent)

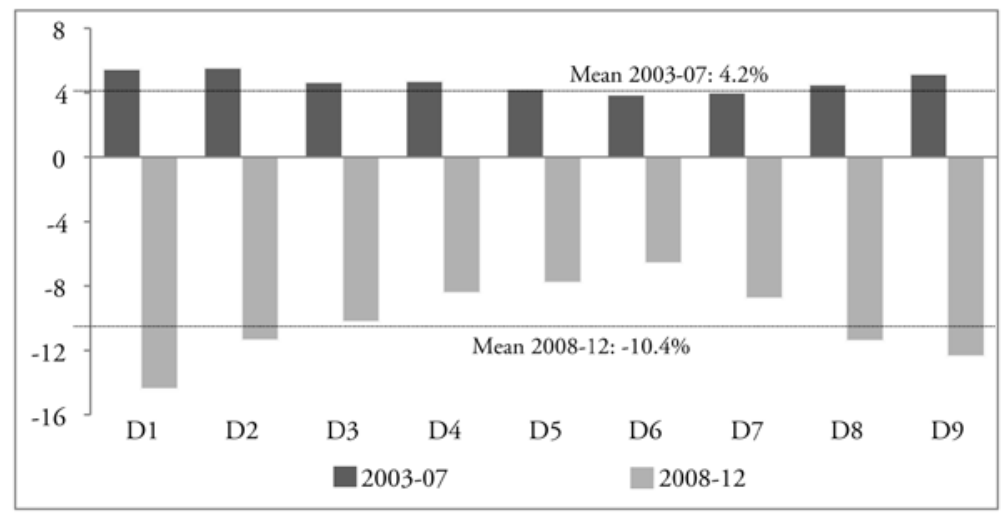

Source: Elaboration on HBS public-use data files.

The continuous line marked by diamonds corresponds to the relative poverty rate computed by classifying as poor any childless couple whose expenditure falls below the national per capita mean. ${ }^{17}$ After a period of little variation, in 2012 the share of poor persons suddenly jumped from 13.6 to 15.8 percent. This sharp rise seems, however, to capture movements just around the standard poverty line: there appears to be no significant change when the line is either lowered by a fifth or increased by a fifth (see the continuous lines marked by squares and triangles, respectively). On the other hand, it should be borne in mind that, from 2007 to 2012, poverty standards shrank, as the fall of real per capita expenditure by 9.1 percent led to an equal reduction of the poverty line at constant prices. Should the line be kept constant at the 2007 level in real terms, the growth of poverty ratios would begin in 2008 and would then accelerate in 2012 (see the dotted lines starting in 2007). These last series are based on a pseudoabsolute approach in the sense that the poverty reference is fully relative in the base year (2007), but is then updated only for inflation. The two bottom lines in figure 5, marked by empty circles, show instead truly absolute poverty rates: the thresholds are calculated as the cost of a minimum bundle of goods and services in their respective base years. ${ }^{18}$ Although on lower levels, the pattern of the absolute poverty rate parallels that obtained with a standard line anchored at 2007: a rise since 2008, which sped up in 2012.

These dynamics are mirrored by the changes at the top of the distribution. The "affluence ratio" can be computed as the share of 
FIGURE 5 Headcount Poverty Ratios (percent)

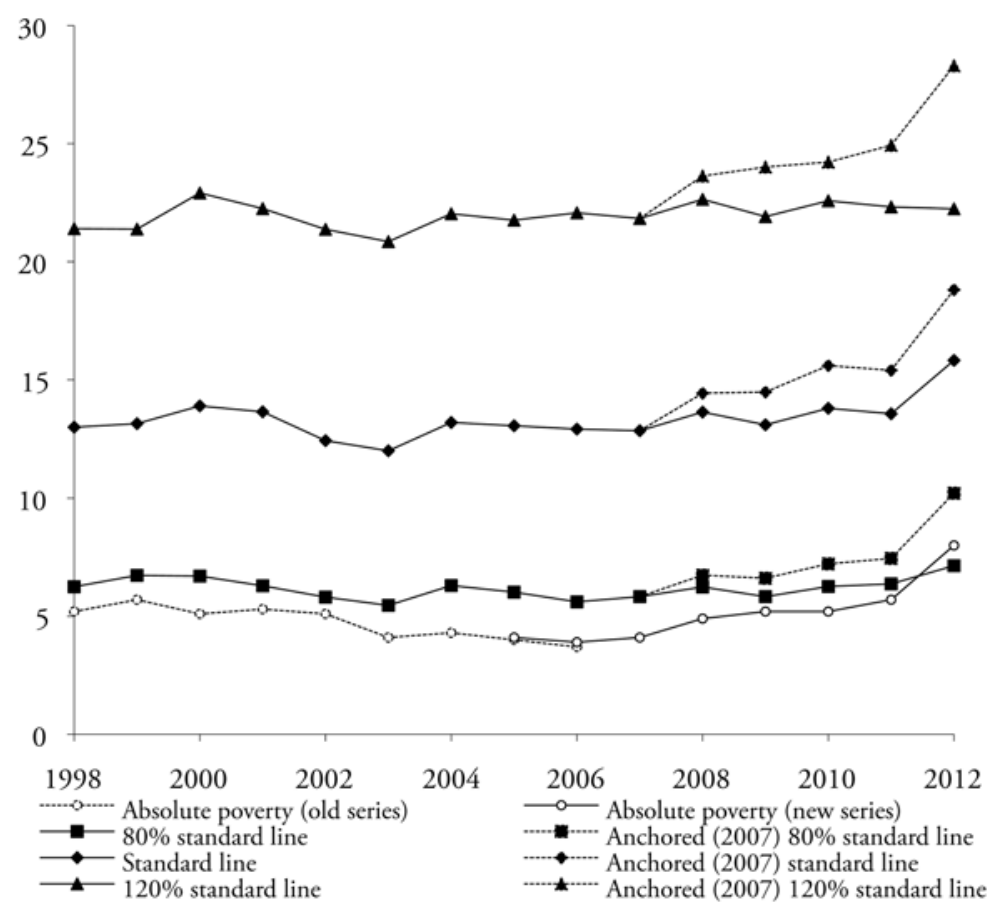

Source: Elaboration on HBS public-use data files.

people whose equalized expenditure exceeds a certain threshold. By setting such a threshold at four times the national per capita income, the affluence ratio decreased from 8.1 percent in 2007 to 7.2 percent in 2012-and to 5.4 percent, if the cut-off is anchored at the 2007 level in real terms.

In brief, the contraction of household expenditure since 2007 has affected the whole distribution, although somewhat more intensely at either extreme. The distribution has not polarized; rather, it has shifted downward. Rising poverty ratios have been accompanied by a falling proportion of people with high levels of spending. However, the causes of these variations differ. The difficulties at the bottom may reveal the flaws of the Italian social safety net in coping with a depressed economy and a weak labor market, while the worsening at the top may be reasonably linked to the substantial drop in returns on property, including capital losses. 


\section{Material Deprivation and the Composition of the Poor Population}

Roughly the same pattern observed for the absolute headcount rates is exhibited by most indicators of material deprivation and, with some qualification, of self-assessed personal economic conditions. Eurostat's concept of material deprivation captures the lack of durable goods and the inability to make certain purchases owing to the absence of economic resources. The underlying indicators are gathered by ISTAT in the Statistics on Income and Living Conditions (SILC) survey conducted in the last quarter of each year. ${ }^{19}$ According to the indicator adopted for the "Europe 2020" strategy, ${ }^{20}$ a person is severely materially deprived if he or she lives in a household lacking at least four out of nine predefined social necessities. The proportion of severely deprived persons increased only slightly between 2007 and 2008 and then very sharply in 2011-2012. Most elementary indicators moved in a similar manner (table 1). On the other hand, the proportion of people who were unable to make ends meet rose in 2008 but subsequently stabilized at a somewhat lower level. Lastly, indicators of self-assessed personal economic conditions show a spike in 2008 and again in 2012-2013. The first spike cannot be linked to the Great Recession, as data are collected by ISTAT in its Multi-Purpose Survey (MPS) carried out in February.

In general, the increase in poverty and deprivation was not accompanied by changes in the composition of the poor population. The incidence of both relative and absolute poverty tended to go up relatively more in socio-demographic sub-groups where it was already higher (fig. 6). Thus, it grew more in southern than in northern and central regions, ${ }^{21}$ among tenants than homeowners, and among households of skilled and unskilled manual workers and "quasi-employees"-individuals who work for single customers in their premises but are formally self-employed to reduce social security contributions and employment protection-than among households of managers, entrepreneurs, and salaried and independent professionals. There is, however, one notable feature in figure 6: the economic contraction has hit the young more than adults and especially the elderly. Old single persons and old childless couples were the only groups to show a fall or a virtual stability in the headcount poverty rates between 2007 and 2012. Such a result is hardly surprising, given that the elderly are not affected by fading job opportunities while being sheltered by the pension system. This pattern is common to most countries hit by the Great Recession, ${ }^{22}$ but it is possibly more pronounced in Italy, owing to the structure of its social safety net. As is well known, Italy stands 
FIGURE 6 Headcount Relative and Absolute Poverty Rates, by Occupation of Household Head, Household Type, and Region of Residence (percent and percentage points)

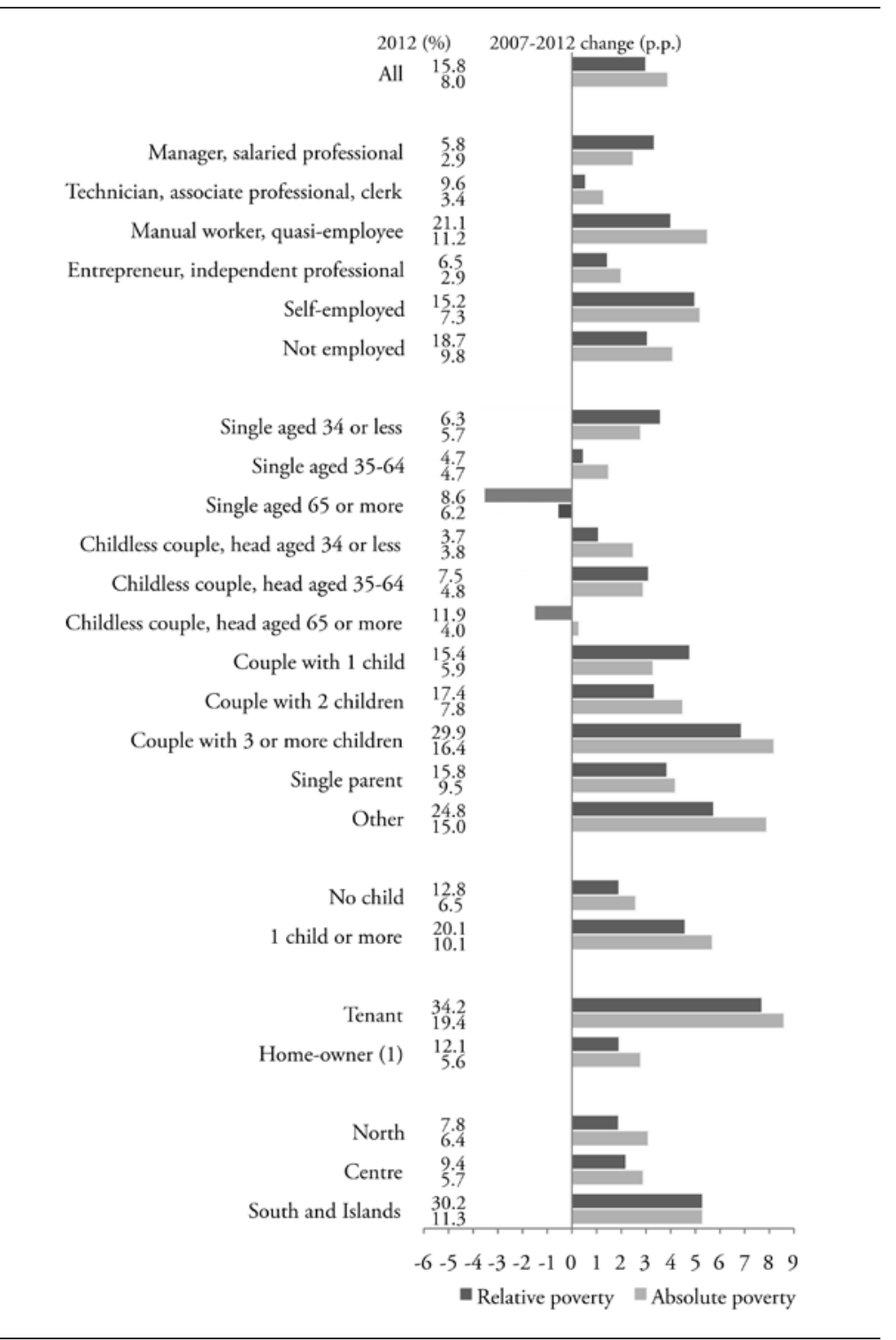

Notes: In the column with the poverty values for 2012 , the figure above is the relative rate and the one below is the absolute rate. (1) Includes also home occupation under a redemption agreement, in usufruct and free of charge (i.e., loaned by friends or relatives).

Source: Elaboration on HBS public-use data files. 
out among European countries for having the largest share of pension spending in the total gross expenditure for social protection. Conversely, the expenditure on benefits for unemployment, family and children, housing, and social exclusion is among the lowest: in 2011, it amounted to approximately 580 euros per head, around half of the Spanish and British values and one-third of the German, French, and Swedish values. ${ }^{23}$ This feature of social protection can partly account for the higher incidence of poverty among households with children and for its above-average increase in the last five years. In 2012, the share of children ( $0-17$ years) living in absolute poverty rose to 10.3 percent, against the 8.0 percent of adults (18-64 years) and the 5.8 percent of the elderly (65 years or more).

\section{Labor Market Developments and the Distribution of Income among Taxpayers}

The Great Recession interrupted a period when employment had been expanding at a quicker pace than macro-economic conditions would have justified. This had largely been the consequence of the greater "flexibility" introduced in the labor market by legislative changes and contractual agreements. ${ }^{24}$ About two-fifths of the 2.8 million additional salaried jobs created between 1997 and 2007 were on a fixedterm basis. During the same period, real wages per full-time employee rose slowly, by 0.5 percent per year. Real earnings at first employment progressively decreased. ${ }^{25}$ This led to a worsening of the youth condition in the labor market that "was due less to shrinking occupational chances ... than to declining earning levels and increasing uncertainty about career prospects." 26

Since the start of the recession, employment has sluggishly followed the dynamics of GDP. According to ISTAT's Labor Force Survey (LFS), seasonally adjusted employment diminished by 3.1 percent from April 2008 to August 2010. The subsequent recovery was modest and lasted until the spring of 2012. Ever since, employment has been falling steadily. In December 2013, the number of employed diminished by over 1.2 million, or 5.3 percent, lower than its peak in 2008. Employers initially reduced working time and stopped replacing workers leaving for retirement or termination of a fixed-term contract, but they eventually turned to shedding jobs. On the basis of LFS data, job terminations rose by 6 percent between 2007 and 2012. ${ }^{27}$ Those caused by the end of a fixed-term contract, more than half of the total, went up by 9 percent. But the deepening of the economic crisis shows up in the increase of job losses due to shutdowns ( 47 percent) and layoffs ( 72 percent). The 
increase in transitions out of employment, however, played a quantitatively smaller role than the decrease in transitions into employment. ${ }^{28}$ From 2007 to 2012, the number of job-seekers increased by 81 percent, while the number of discouraged workers and of persons waiting for an answer to a previous job-search action, both classified outside the labor force, increased by 25 percent and 48 percent, respectively. In December 2013, 3.2 million persons were unemployed, and another 2.5 million were not actively searching because they were waiting to hear back about a job or because they were discouraged.

The contraction in employment levels is noticeable in the reduction of the number of people filing annual tax returns. According to tax records, ${ }^{29}$ between 2007 and 2011 the number of taxpayers with a positive income fell by 640,000 , or 1.5 percent, although the number of people older than 19 years rose by $740,000 .{ }^{30}$ Mean real taxable income diminished by 1.3 percent. ${ }^{31}$ The decline was much stronger than the mean at the bottom of the distribution, where "marginal" taxpayers with highly variable and often occasionally low incomes are concentrated. Changes were hardly noticeable for all middle deciles and turned into small losses for the top three deciles. The share of total income held by the top 1 percent of earners declined slightly from 9.5 to 9.1 percent, while that of the next 4 percent remained stable at 13.6 percent. The Gini coefficient was virtually unchanged (45.9 percent in 2007 and 45.7 percent in 2011). In brief, the impact of the two recent recessions on the overall distribution of pre-tax positive incomes among taxpayers was modest in size, except for the losses at the bottom.

This result does not account for the increasing number of people who did not file any tax return. If all individuals aged 20 years or more who are missing from tax records were hypothetically assigned a nil income, the Gini coefficient would have gone up from 52.8 percent in 2007 to 54.1 in 2011. Yet the impression of a stasis amid a most severe recession is somewhat surprising. The stasis extends also to the five years before, when the increase in mean real taxable income by 4.6 percent spread rather evenly across deciles, except for a better performance at the bottom. In both episodes, however, the image of a static distribution fades away when taxpayers are divided into three groups: employees, pensioners, and a residual group comprising self-employed people and all other taxpayers. ${ }^{32}$ In 2009, 2010, and 2011, these groups accounted for 51, 37, and 12 percent of all taxpayers, respectively. Real pre-tax incomes of employees fell during the recessions more intensely than in the previous five years. The decline waned when moving higher up in the distribution, implying growing within-group inequality. In contrast, pensioners' incomes showed a steady and fairly homogeneous increase in both periods, with the partial exception of 
the lowest 10 percent; disparities among pensioners slightly narrowed. The third group mostly comprises self-employed taxpayers and, unsurprisingly, has by far the most variable incomes: the relatively sustained growth between 2002 and 2007 was reversed in the next four years. Income inequality within this group rose during the recessions, inverting the previous downward trend.

The apparent stability of the pre-tax income distribution hides important re-rankings across, and within, main categories of taxpayers. The economic downturn led to a complete reversal of the ascending pre-crisis trend for the incomes of self-employed taxpayers and to a strengthening of the already negative tendency for employees' incomes. Only for pensioners have incomes kept growing throughout the recession. ${ }^{33}$

\section{The Distribution of Household Income and Wealth}

Tax data provide insightful information about recent distributive changes. Tax evasion aside, they have, however, two shortcomings. First, they are silent about changes induced by variations in the income earned on financial assets, which is an important factor in the recent decline of household incomes. Second, tax data refer to individual taxpayers and thus do not provide data about non-tax filers or about income pooling within the household. The sharing of family resources is a distinctive feature of southern European "welfare regimes." 34 During the downturn, the role of family ties in protecting the living standards of young job-losers, especially those still residing with their parents, was magnified by the pattern of job losses. ${ }^{35}$

The Bank of Italy's Survey of Household Income and Wealth (SHIW) and ISTAT's SILC survey provide the richer household-level information necessary to account for these aspects. These surveys differ in methodology but adopt a comprehensive definition of income including all cash incomes earned by the household, net of income taxes and social security contributions. The imputed rent of owneroccupied dwellings is comprised in the SHIW figures but not in the SILC statistics published by Eurostat. The SHIW estimates household net worth as the sum of all real and financial assets, net of liabilities. Both income and wealth (deflated by the deflator of household final consumption) are equalized with the modified OECD equivalence scale $^{36}$ and are then attributed to each household's member.

The SHIW data confirm that the Great Recession was a turning point for household income dynamics: the real increase by 11.2 percent in the six years $2001-2006$ was replaced by a decline of 13.8 percent in the next six years. Both the increase and the decline were larger in the 
bottom half of the distribution (fig. 7). The comparison between a fall above the mean for expenditure and below the mean for income hints that other factors, such as capital losses, contributed to depress the consumption of the richest households. ${ }^{37}$ All in all, both the concentration of the equalized income distribution, as measured by the Gini coefficient, and the relative poverty ratio, based on a threshold set at 60 percent of the median equalized income, have not varied much since the pre-crisis years (table 1). Only the anchored low-income ratio surged, following the decrease in real thresholds caused by falling real incomes. By and large, the SILC statistics on income inequality and poverty, available up to 2011, do not contradict the SHIW evidence, although levels and the timing of changes may differ somewhat.

Equalized household net worth also diminished, by almost 6 percent from 2006 to 2012. The drop across the entire distribution was qualitatively similar to that of income. But cross-decile differences were more pronounced, and the Gini coefficient rose by two percentage points to 64 percent in 2012. Asset-poor households can be defined as those with net worth falling short of the amount that is necessary to sustain them at the income poverty line for a given period. ${ }^{38}$ Taking six months as the reference period, ${ }^{39}$ the share of persons who are both asset- and income-poor remained approximately constant around 8 percent from 2000 to 2006 but then rose to 9.8 percent in 2008 and 11 percent in 2010 and 2012. The increase during recessions is much sharper for young households. ${ }^{40}$

Since the Great Recession, the economic conditions of young households (head aged 39 or less) have clearly deteriorated relative to those

FIGURE 7 Changes in Household Equivalized Income, by Decile (percent)

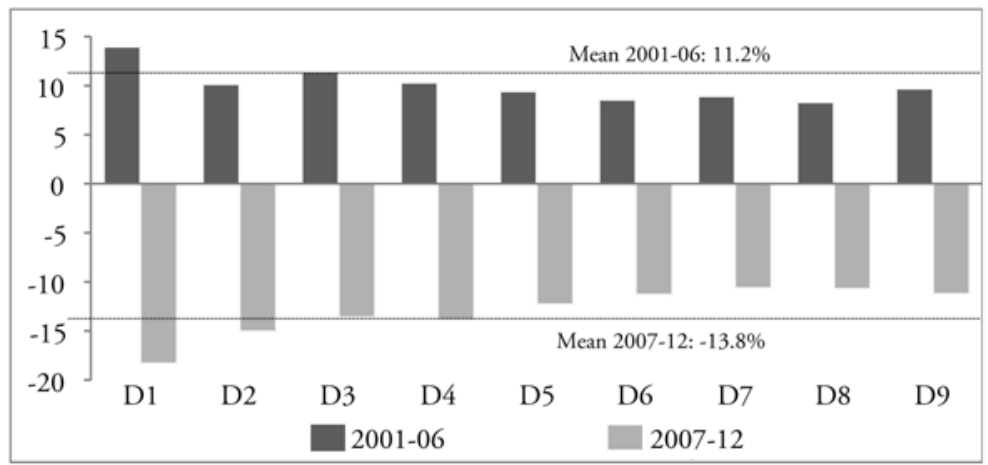

Source: Elaboration on SHIW public-use data files 
of adult households (head aged 40-59) and especially of elderly households (head aged 60 or more). This is evident by looking at the presence of the three groups in each fifth of population sorted by increasing equalized income or wealth. The bars in figure 8 show the excess of these shares over 20 percent, which is the share that would attain if the three groups were equally spread across the distributions. Young households are over-represented in the bottom two-fifths, while the opposite happens for elderly households. The difference between the two groups has greatly widened in 2012 relative to 2000 and 2006, more for income (top panels) than for wealth (bottom panels). The age gradient in the dynamics of economic resources is a most disturbing legacy of the recent downturn.

\section{Concluding Remarks}

The Great Recession, imported from abroad, and the subsequent sovereign debt crisis, fueled by old weaknesses of the country's public finances, have somewhat obfuscated the concern voiced in the past decade that Italy was sliding onto a path of economic decline. Yet it would be misleading to see the collapse of real incomes experienced by Italian households in the last five years simply as the result of a very severe economic contraction. The impact of the two recessions on living standards must be seen in the context of an economy that had been stagnating for almost a decade, with household finances strained by modest income growth and increased occupational insecurity and pressed by the need of the government to carry out a painful fiscal consolidation.

During the Great Recession, discretionary measures and automatic stabilizers provided an income support that was smaller than in other advanced economies; nevertheless, it was important to prevent a deterioration of the distribution of economic resources. The evidence presented in this chapter confirms that the impact of the economic downturn on inequality and poverty was fairly limited, when compared with the size of the fall in mean incomes. The effects of the downturn were felt more by non-elderly households than elderly households, who were largely shielded from the income fall. In the short run, the impact was relatively mild, thanks to the fact that workers who were more likely to lose their jobs were not breadwinners, that a large share of the population relied on pension income, and that high wealth holdings and low indebtedness helped households to smooth out the repercussions of the negative shock on consumption expenditure. 


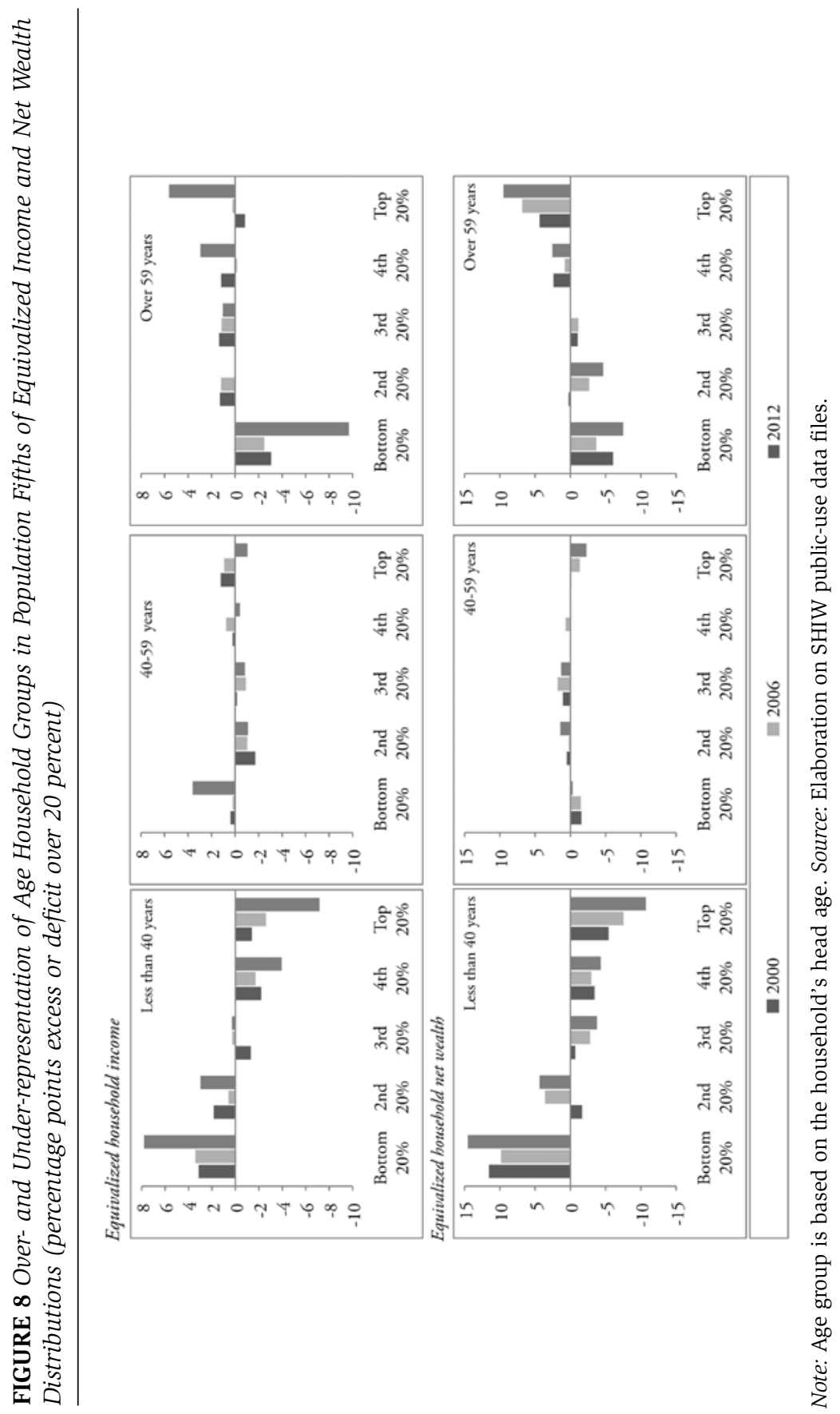


The reversal in public policies brought about by the implementation of austerity measures and the new economic contraction associated with the sovereign debt crisis further raised the pressure on household budgets, but in an already deteriorated situation, where the buffer of net worth had been severely eroded. Measures of poverty and deprivation have started to increase in the last couple of years, although inequality indices have not yet changed much, possibly because of simultaneous losses at the top of the distribution.

The medium-term outlook is uncertain. A great deal depends on the capacity of the Italian economy to regain a growth path. In the longer run, the question is whether recent events will impair the prospects of the young generations. In the spring of 2008, prior to the Great Recession, 65 percent of Italians interviewed in the Eurobarometer survey thought that the life of their children's generation would be more difficult than that of their own generation; only 7 percent expected an improvement in living conditions ${ }^{41}$ The available data do not allow us to measure precisely intergenerational progress in living standards, but econometric analyses of the SHIW incomes show that the progress was steady and substantial for the cohorts born in the first half of the twentieth century, which benefited most from the strong economic growth of the post-war Golden Age. ${ }^{42}$ This upward trend gradually attenuated and virtually came to a halt for the generations born since the 1970s.

It is unclear whether this slowdown might turn into regress, but prospects for the living standards of the young generations are bleaker in Italy than in other rich countries for which comparable data are available. The severity of the economic contraction of the last five years and the way that it has affected age cohorts are likely to have worsened not only people's expectations but also actual tendencies.

\section{Acknowledgments}

For useful comments and help with the data, I thank Andrea Alivernini, Massimo Coletta, Francesco D’Amuri, Carlo Fusaro, Federico Giorgi, Giuseppe Grande, Amie Kreppel, Michele Loberto, Alessandra Masi, Nicoletta Pannuzi, Eugenio Peluso, Giordano Zevi, and Francesco Zollino. The views expressed here are solely those of the author; in particular, they do not necessarily reflect those of the Bank of Italy.

Andrea Brandolini is an economist in the Directorate-General for Economics, Statistics, and Research of the Bank of Italy. 


\section{Notes}

1. P. Ciocca, "The Italian Economy: A Problem of Growth," Economic Bulletin 37 (2003): 145-158; A. Brandolini, and M. Bugamelli, eds., "Reports on Trends in the Italian Productive System,” Occasional Paper No. 45, Bank of Italy, Rome, 2009.

2. M. Bugamelli, R. Cristadoro, and G. Zevi, "International Crisis and the Italian Productive System: An Analysis of Firm-Level Data," Giornale degli Economisti e Annali di Economia 69, no. 2 (2010): 155-188.

3. M. Caivano, L. Rodano, and S. Siviero, "The Transmission of the Global Financial Crisis to the Italian Economy," Giornale degli Economisti e Annali di Economia 70, no. 3: (2011): 1-32.

4. F. Busetti and P. Cova, "L'impatto macroeconomico della crisi del debito sovrano: Un'analisi contro fattuale per l'economia italiana," Occasional Paper No. 201, Bank of Italy, Rome, 2013.

5. This observation relates to the factual consequences of austerity measures and bears no implication for their appropriateness. Given the size of the Italian public debt, the considerable fiscal adjustment implemented since 2011 was hardly an avoidable response to the tensions in the financial markets. A deferral of such an adjustment would have led, most likely, to a greater deterioration of credit conditions and eventually to a worse GDP dynamics than the one actually observed.

6. ISTAT, Notifica dell'indebitamento netto e del debito delle amministrazioni pubbliche secondo il trattato di Maastricht, informative report, table 1, 22 April 2013, http://www.istat.it/it/archivio/88546.

7. S. P. Jenkins, A. Brandolini, J. Micklewright, and B. Nolan, eds., The Great Recession and the Distribution of Household Income (Oxford: Oxford University Press, 2013), 40, 44.

8. L. Guiso, M. Paiella, and I. Visco, "Do Capital Gains Affect Consumption? Estimates of Wealth Effects from Italian Households' Behavior,” in LongRun Growth and Short-Run Stabilization: Essays in Memory of Albert Ando, ed. L. R. Klein (Cheltenham: Edward Elgar), 46-82; and A. Bassanetti and F. Zollino, "The Effects of Housing and Financial Wealth on Personal Consumption: Aggregate Evidence for Italian Households," in Housing Markets in Europe: A Macroeconomic Perspective, ed. O. de Bandt, T. Knetsch, J. Peñalosa, and F. Zollino (Heidelberg: Springer, 2010), 307-336.

9. G. Gobbi and F. Zollino, "Tendenze recenti del mercato immobiliare e del credito," in Le tendenze del mercato immobiliare: L'Italia e il confronto internazionale, ed. R. De Bonis, A. Lamorgese, R. Sabbatini, and F. Zollino (Rome: Bank of Italy, 2013), 9-36.

10. A. Alivernini and D. Caprara, "Household Wealth in Italy: 2011," Supplement to the Statistical Bulletin, Monetary and Financial Indicator No. 65, Bank of Italy, Rome, 2012.

11. This figure is based on estimates according to which a permanent capital loss of 1 percent leads to a decrease in consumption by around 0.11 percentage points when incurred on financial wealth and by 0.08 points when incurred on housing wealth. See Bassanetti and Zollino, "The Effects of Housing and Financial Wealth on Personal Consumption.” 
12. ISTAT, La stima ufficiale della povertà in Italia, 1997-2000 (Rome: ISTAT, 2002).

13. The equivalence scale assigns weight 1 to a household of two persons and then weights 0.6 to a single person, 1.33 to three persons, 1.63 to four persons, 1.9 to five persons, 2.16 to six persons, and 2.4 to seven or more persons.

14. The dynamics of household expenditure in the HBS are broadly in linebut far from perfectly coincident-with those in national accounts. During the years 2003-2007, real expenditure per capita rose by 6 percent in the HBS and 3 percent in national accounts; in the next five years it declined by 9.1 and 7 percent, respectively. Methodological and definitional differences, as well as weaknesses in either source, can explain these misalignments. Similar considerations apply to the income data discussed below.

15. A decile is any of the equalized expenditure values that separate subsequent tenths of the population sorted by increasing equalized expenditure: the poorest 10 percent spends for consumption less than the first decile $\mathrm{D} 1$, while the remaining 90 percent spends more than that, and so forth.

16. ISTAT, La povertà in Italia: Anno 2012, statistical report, 17 July 2013, http://www.istat.it/it/archivio/95778.

17. Thresholds for households of different sizes are implicitly defined by the scale used to equalize expenditure.

18. In spite of the similar level in the overlapping years, these two series are derived by applying different methods. In particular, the new series utilizes a finer grid of thresholds, including a differentiation by macro-region and size of municipality, which was entirely missing in the old series. See ISTAT, La misura della povertà assoluta (Rome: ISTAT, 2009).

19. ISTAT, Households Economic Conditions and Disparities, http://www. istat.it/en/households-economic-conditions (accessed December 2013); and A. B. Atkinson and E. Marlier, eds., "Income and Living Conditions in Europe,” Eurostat, http://epp.eurostat.ec.europa.eu/cache/ITY_OFFPUB/KS-31-10-555/EN/KS-31-10-555-EN.PDF (accessed December 2013).

20. European Commission, "Europe 2020: A European Strategy for Smart, Sustainable and Inclusive Growth,” COM(2010) 2020 final, 3 March 2010, http://ec.europa.eu/europe2020/index_en.htm.

21. The adjustment for territorial cost-of-living differences embodied in the absolute standard narrows but does not wipe out the North-South divide.

22. Jenkins et al., The Great Recession, 241-242.

23. The actual estimates are expressed in purchasing power standards (PPS), a fictitious currency used by Eurostat to adjust for cross-country differences in price levels. At the Italian price level, values in PPS are close to those in euros. Eurostat, “Social Protection,” http://epp.eurostat.ec.europa.eu/ portal/page/portal/social_protection/introduction (accessed 30 January 2014).

24. A. Brandolini, P. Casadio, P. Cipollone, M. Magnani, A. Rosolia, and R. Torrini, "Employment Growth in Italy in the 1990s: Institutional Arrangements and Market Forces," in Social Pacts, Employment and Growth: A 
Reappraisal of Ezio Tarantelli's Thought, ed. N. Acocella and R. Leoni (Heidelberg: Physica Verlag, 2007), 31-68.

25. A. Rosolia, "L'evoluzione delle retribuzioni in Italia tra il 1986 e il 2004 secondo i dati dell'archivio WHIP," Politica Economica 26, no. 2 (2010): 179-201; A. Rosolia and R. Torrini, "The Generation Gap," Working Paper No. 639, Bank of Italy, Rome, 2007.

26. F. Giorgi, A. Rosolia, R. Torrini, and U. Trivellato, "Mutamenti tra generazioni nelle condizioni lavorative giovanili," in Generazioni disuguali. Le condizioni di vita dei giovani di ieri e di oggi: Un confronto, ed. A. Schizzerotto, U. Trivellato, and N. Sartor (Bologna: Il Mulino, 2011), $111-144$.

27. The number of quarterly job terminations is approximated by the number of non-employed persons who have terminated their occupation in the three months prior to the interview, lagged one quarter. These estimates are net of the terminations followed by a new hire within the three months.

28. F. D'Amuri, "The Impact of the Great Recession on the Italian Labour Market," Research in Labor Economics 32 (2011): 155-179; and A. Brandolini, F. D’Amuri, and I. Faiella, "Country Case Study-Italy,” in Jenkins et al., The Great Recession, 130-152.

29. Department of Finance, Dichiarazioni fiscali (Rome: Department of Finance, 2013), http://www.finanze.it.

30. Non-positive incomes are excluded since they are missing for 2007. They came to more than half a million per year in 2009-2011. Incomes are divided by the deflator of household final consumption.

31. Taxable income is net of interest and (a large part of) dividends, which are mostly subject to flat-rate withholding taxes, and does not include capital gains and losses.

32. This is the only available breakdown in the current tabulations of tax statistics. The classification is based on taxpayers' declarations, regardless of their actual main source of income.

33. In the 15 years prior to the Great Recession, a substantial stability of the overall income inequality indices was also accompanied by sizable differences across occupational groups, namely, by an improvement of the relative position of the households of self-employed workers, managers, and, to a lesser extent, pensioners and by a worsening in the relative position of the households of white-collar and (especially) blue-collar workers. See A. Brandolini, "L'evoluzione recente della distribuzione del reddito in Italia,” in Dimensioni della disuguaglianza in Italia: Povertà, salute, abitazione, ed. A. Brandolini, C. Saraceno, and A. Schizzerotto (Bologna: Il Mulino, 2009), 39-67.

34. M. Ferrera, “The 'Southern Model' of Welfare in Social Europe,” Journal of European Social Policy 6, no. 1 (1996): 17-37; M. Albertini, M. Kohli, and C. Vogel, "Intergenerational Transfers of Time and Money in European Families: Common Patterns-Different Regimes?” Journal of European Social Policy 17, no. 4 (2007): 319-334; M. Albertini and M. Kohli, "The Generational Contract in the Family: An Analysis of Transfer Regimes in Europe,” European Sociological Review 29, no. 4 (2013): $828-840$. 
35. S. Mocetti, E. Olivieri, and E. Viviano, "Le famiglie italiane e il lavoro: Caratteristiche strutturali e effetti della crisi," Stato e Mercato, no. 2 (2011): $223-243$.

36. This scale assigns value 1 to the first adult, 0.5 to any other person aged 14 or older, and 0.3 to each child younger than 14 .

37. Distributive effects of changes in asset prices can be significant. Bassanetti et al. estimate that the growth in Italian housing prices between 2000 and 2007 redistributed welfare-as measured by an increasing concave function of consumption-away from poor renter households to rich homeowners and benefited young cohorts less than middle-aged and retired cohorts. See A. Bassanetti, C. Rondinelli, and F. Scoccianti, "The Welfare Consequences of a Booming Property Market,” mimeo, Bank of Italy, 2013.

38. A. Brandolini, S. Magri, and T. M. Smeeding, "Asset-Based Measurement of Poverty," Journal of Policy Analysis and Management 29, no. 2 (2010): 267-284.

39. With an income poverty threshold set at 60 percent of the median equivalized income, the wealth threshold is then 30 percent of this median value.

40. L. Bartiloro and C. Rampazzi, "Il risparmio e la ricchezza delle famiglie italiane durante la crisi,” Occasional Paper No. 148, Bank of Italy, Rome, 2013.

41. European Commission, "Eurobarometer 69: Public Opinion in the European Union,” Annexes, Table QA29, 2008, http://ec.europa.eu/public_ opinion/archives/eb/eb69/eb69_it_nat.pdf.

42. A. Brandolini and G. D’Alessio, "Disparità intergenerazionali nei redditi familiari,” in Schizzerotto et al., Generazioni disuguali, 145-173. 